\title{
Effect of temperature and the role of testicular descent on post-natal testicular androgen production in the mouse
}

\author{
P. J. O'Shaughnessy and J. W. Sheffield \\ Department of Veterinary Basic Sciences, Royal Veterinary College, Royal College Street, \\ London NWI OTU, UK
}

\begin{abstract}
Summary. Testes from mice aged 3, 15, 25, 30 or 60 days were incubated under basal conditions or in the presence of hCG. One testis from each animal was incubated at $37^{\circ} \mathrm{C}$ while the contralateral testis was incubated at 32 or $34^{\circ} \mathrm{C}$. During development total androgen production in response to hCG (at $32^{\circ} \mathrm{C}$ ) showed a marked increase between 15 and 30 days. The major androgens secreted at this time were testosterone and $5 \alpha$-androstane- $3 \alpha, 17 \beta$-diol. There was little change in total androgen production between 30 and 60 days but by 60 days testosterone was the dominant androgen. Both basal and hCG-stimulated androgen production were temperature sensitive. These effects were most pronounced at 30 and 60 days with androgen production significantly inhibited at $37^{\circ} \mathrm{C}$. To examine the role of testicular descent in regulating steroidogenesis animals were rendered unilaterally cryptorchid at 19 days of age. At 25 days, when descent is normally completed in the mouse, there was no significant difference in steroidogenesis between scrotal and abdominal testes. By 30 days, however, the steroidogenic potential of the abdominal testis was significantly lower than that of the scrotal testis.

These results show that testicular steroidogenesis is sensitive to temperature changes around the time of testicular descent, although descent itself is not required to achieve an adult level of steroidogenesis. The results also show, however, that testicular descent is required to maintain the adult level of steroidogenesis.
\end{abstract}

Keywords: temperature; testis; androgen; mouse; development; cyrptorchid

\section{Introduction}

The adult testes of most mammalian species are extra-abdominal and function at a temperature lower than normal body temperature. This temperature difference is necessary to maintain spermatogenesis although the evolutionary reason for this requirement is unclear (Bedford, 1978). Cryptorchidism, which elevates testicular temperature, disrupts spermatogenesis and leads to infertility (Moore \& Chase, 1923). This condition also affects both morphology and function of the Sertoli and Leydig cells of the testis (Van Straaten et al., 1978; Hagenas \& Ritzen, 1976; Kerr et al., 1979; Seethalakshmi \& Steinberger, 1983; Jegou et al., 1984; Farrer et al., 1985). These effects of cryptorchidism on the somatic cells of the testis may be due to elevated temperature or to indirect effects such as inhibition of steroidogenesis or changes in testicular blood flow (Damber et al., 1978). Results from Hall et al. (1985) suggest that Sertoli cells in culture are more active at $38^{\circ} \mathrm{C}$ than at $32^{\circ} \mathrm{C}$ and that the inhibitory effects of cryptorchidism on Sertoli cells are likely, therefore, to be indirect. The effects of temperature on Leydig cell function are less clear. It has been shown that serum or testicular androgen concentrations are decreased in rams (Gomes et al., 1971), bulls (Rhynes \& Ewing, 1973) and boars (Wettemann \& Desjardins, 1979) exposed to high ambient temperatures. In contrast, Dufau et al. (1971) failed to observe an effect of varying temperature 
between 32 and $37^{\circ} \mathrm{C}$ on testicular steroid production in vitro in the adult rat. It is of importance, however, to determine whether testicular steroidogenesis is affected by temperature since the testes are exposed to marked changes in temperature during development.

In mice, descent of the testes, with the consequent change in ambient temperature, is complete at about Day 25 after birth. Jean-Faucher et al. (1978) have reported that there is a significant rise in plasma and testicular testosterone concentrations between 20 and 30 days in the mouse. This suggests that the normal reduction in testicular temperature after descent affects testicular steroidogenesis and may be required for development of normal adult Leydig cell function. In this report changes in testicular steroidogenesis during development have been studied and the acute sensitivity to changes in temperature has been examined. In addition, the possible role of testicular descent in affecting the normal development of steroidogenesis has been examined.

\section{Materials and Methods}

Materials. Tissue culture medium was purchased from Gibco (Paisley, Strathclyde, UK). Chemicals and hormones were purchased from Sigma Chemical Co. (Poole, Dorset, UK) unless otherwise stated.

Animals. The mice used in this study were derived originally from $\mathrm{FI}$ hybrids of two inbred strains $\mathrm{C} 3 \mathrm{H} / \mathrm{HeH}$ and 101/H (Cattanach et al., 1977). The day of birth was designated as Day 1 and animals were used when aged 3, 15, 25, 30 and 60 days. To examine the role of testicular descent in controlling steroidogenesis animals were rendered unilaterally cryptorchid at Day 19, before the time of normal testicular descent. Animals were anaesthetized and the gubernaculum cut on one side. To ensure that descent did not occur the inguinal ring on that side was sutured. Animals were allowed to recover and testicular steroidogenesis was measured at Days 25 and 30.

Tissue incubations. Mice were killed by decapitation and the testes decapsulated and incubated in Medium 199 containing $0 \cdot 1 \%$ bovine serum albumin, $\mathrm{pH} 7 \cdot 4$. Incubations were for $4 \mathrm{~h}$ under $95 \%$ air $/ 5 \% \mathrm{CO}_{2}$. To examine acute temperature sensitivity during development one testis from each animal was incubated at $37^{\circ} \mathrm{C}$ while the contralateral testis was incubated at 32 or $34^{\circ} \mathrm{C}$ but under otherwise identical conditions. Testes were incubated under basal conditions (medium alone) or in the presence of hCG $(200 \mathrm{mi} . \mathrm{u} . / \mathrm{ml})$. To examine steroidogenesis in unilaterally cryptorchid animals the scrotal and abdominal testes were incubated at $32^{\circ} \mathrm{C}$ for $4 \mathrm{~h}$ under basal conditions or with hCG. At the end of the incubation period the medium was removed and stored frozen until assayed for androgen content.

Radioimmunoassay. Incubation medium was assayed for androstenedione, testosterone and $5 \alpha$-androstane$3 \alpha, 17 \beta$-diol (androstanediol) using radioimmunoassays specific for each hormone as previously described (Sheffield \& O'Shaughnessy, 1989). Total androgen is expressed as the sum of androstenedione, testosterone and androstanediol. The limits of detection of the assays were 125,100 and $250 \mathrm{fmol} / \mathrm{ml}$, respectively, and the intra-assay variations were $9 \cdot 6,5 \cdot 9$ and $10 \cdot 6 \%$, respectively.

Calculations. The effects of temperature were analysed by paired $t$ tests, data from each testis being paired with the contralateral testis which was incubated at a different temperature but under otherwise identical conditions. This removes the variation in androgen production observed between animals. Other results were analysed using $t$ tests. For illustration, results have been pooled and are expressed as mean \pm s.e.m.

\section{Results}

\section{Androgen production during development}

Changes in testicular steroidogenesis during post-natal development in the mouse are shown in Fig. 1. It is clear that marked changes occur during development of the testis both in the capacity for steroidogenesis and in the types of androgens produced. At all ages the testes were responsive to hCG stimulation. Up to 15 days steroid production was low with testosterone the major androgen produced. By 25 days there was a marked increase in hCG-stimulated androgen production per testis with the $5 \alpha$-reduced steroid androstanediol predominating. Between 25 and 30 days hCGstimulated androgen production continued to increase with high concentrations of both testosterone and androstanediol. Total androgen production did not increase between 30 and 60 days but 
there was a reduction in the synthesis of androstanediol with a corresponding increase in testosterone. Basal androgen production showed similar changes although testosterone remained the predominant steroid throughout. Basal production also continued to show a marked increase between 30 and 60 days.

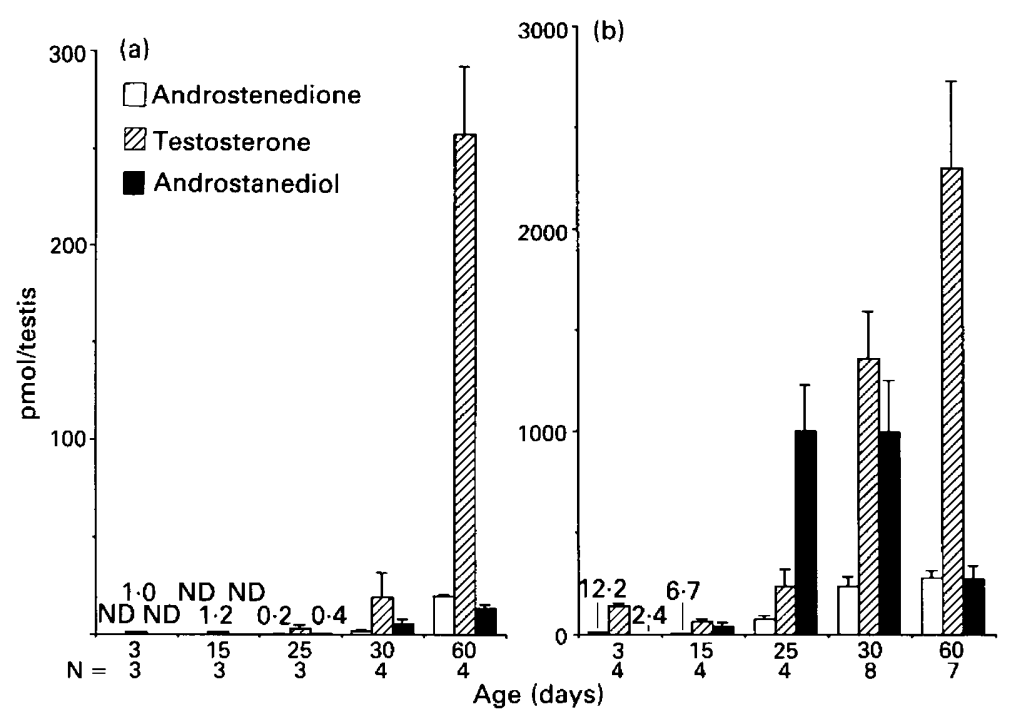

Fig. 1. Basal (a) and hCG-stimulated (b) androgen production at $32^{\circ} \mathrm{C}$ in vitro during development in the mouse. When androgen production is too low to show clearly on the graph the mean value is shown above the corresponding histogram. ND = not detectable. Values are mean \pm s.e.m. for the no. of mice indicated $(\mathrm{N})$.

Changes in testicular weight during the same period of development are shown in Fig. 2. During the period of 15-30 days, when there was a 20-fold increase in steroidogenesis, testis weight increased approximately 5-fold although most of this increase in weight was due to changes in seminiferous tubule mass.

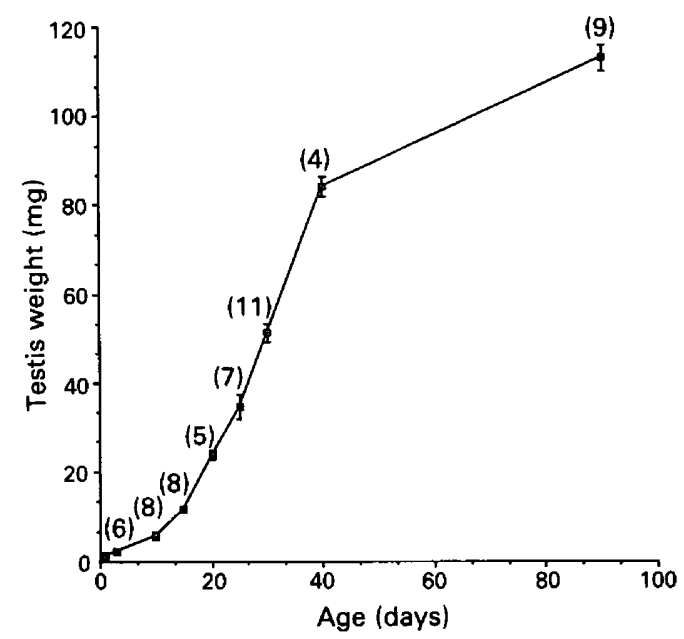

Fig. 2. Testicular weight during development in the mouse. The number of animals measured at each time is indicated in parentheses except for Day 1 when $N=5$. Values are mean \pm s.e.m. 


\section{Effect of temperature on androgen production}

The effect of incubation temperature on androgen production during development is shown in Fig. 3. Testes were incubated at 32 or $34^{\circ} \mathrm{C}$ while the contralateral testis was incubated at $37^{\circ} \mathrm{C}$. At 3 and 15 days there was a slight, but significant, increase in androgen production at lower temperatures. No effect was observed at 25 days while at 30 days there was a clear inhibition of hCGstimulated androgen production at $37^{\circ} \mathrm{C}$. By 60 days testicular steroidogenesis was less sensitive to the inhibitory effects of abdominal temperature although androgen production at $34^{\circ} \mathrm{C}$ was significantly greater than at $37^{\circ} \mathrm{C}$. Similarly, basal androgen production was significantly greater at $32^{\circ} \mathrm{C}$ than at both 34 and $37^{\circ} \mathrm{C}$. The inhibitory effect of abdominal temperature was observed to an equal extent in all three androgens measured. Increasing the incubation temperature to $40^{\circ} \mathrm{C}$ decreased hCG-stimulated androgen production to $39 \pm 15 \%$ of control in testes from 60 -day-old animals while incubation at $42^{\circ} \mathrm{C}$ abolished the steroidogenic response.
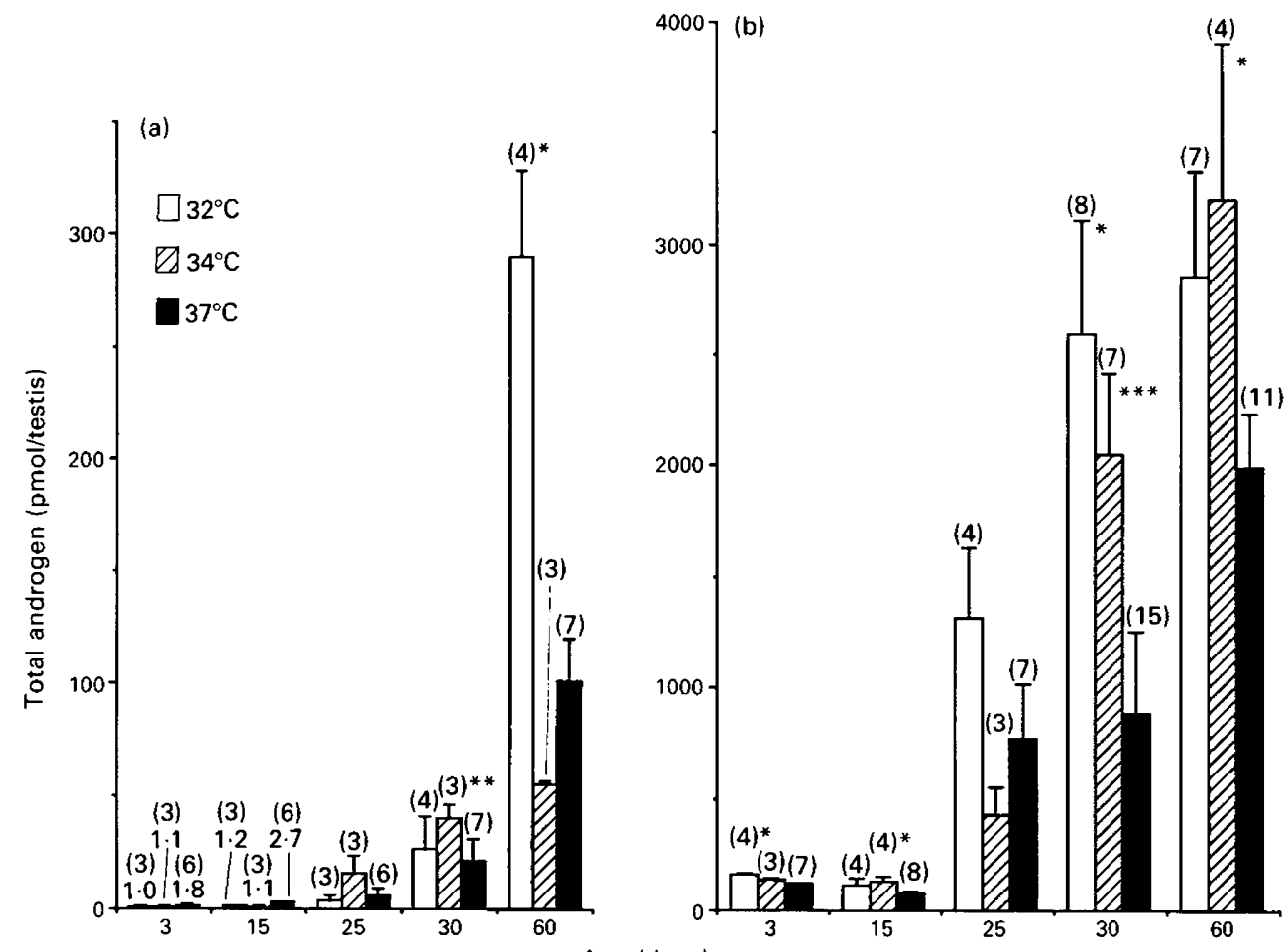

Fig. 3. Effect of incubation temperature on androgen production under basal conditions (a) or in the presence of hCG (b). Total androgen production represents the sum of androstenedione, testosterone and androstanediol. When androgen production is too low to show clearly on the graph the mean value is shown above the corresponding histogram. Values are mean \pm s.e.m. for the no. of animals in parentheses. ${ }^{*} P<0.05,{ }^{* *} P<0.01,{ }^{* * *} P<0.001$ compared with androgen production at $37^{\circ} \mathrm{C}$ (paired $t$ tests). At 60 days the basal androgen production at $32^{\circ} \mathrm{C}$ was also significantly greater than at $34^{\circ} \mathrm{C}(P<0.05, t$ test $)$.

\section{Effect of preventing descent on testicular steroidogenesis}

After induction of unilateral cryptorchidism at Day 19 testicular steroidogenesis at Day 25 did not differ significantly between scrotal and abdominal testes (Fig. 4). By Day 30, however, 
hCG-stimulated androgen production by the abdominal testis was markedly reduced in comparison to the scrotal testis. Between 25 and 30 days the scrotal testis showed a significant increase in weight $(45 \cdot 0 \pm 3 \cdot 5$ to $53 \cdot 9 \pm 2 \cdot 3 \mathrm{mg}, n=18)$ while there was no change in weight of the abdominal testis $(36.7 \pm 0.5 \mathrm{mg}$ at 25 days, $36 \cdot 7 \pm 3.1 \mathrm{mg}$ at 30 days).

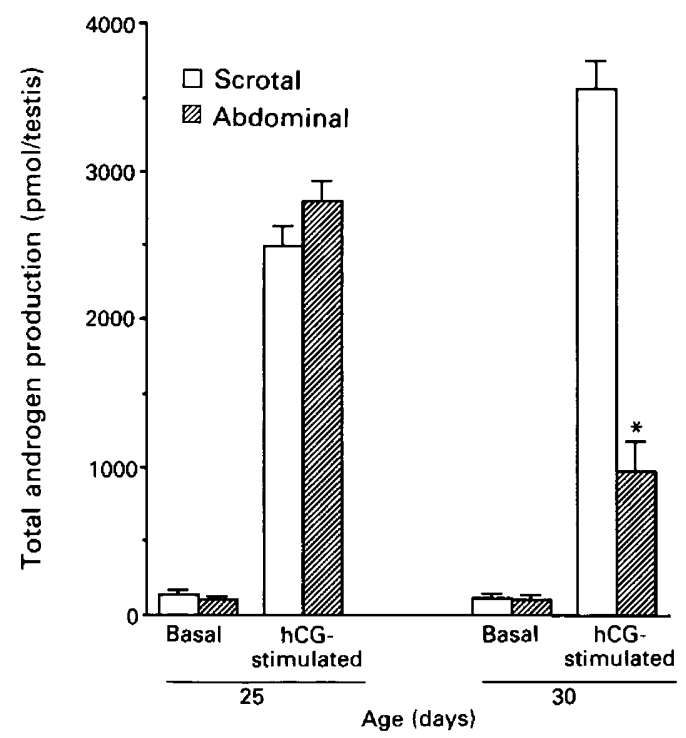

Fig. 4. Effect of preventing testicular descent on subsequent steroidogenic activity. Mice were made unilaterally cryptorchid at 19 days and basal and hCG-stimulated androgen production by the scrotal and abdominal testes were measured in vitro at Days 25 and 30 . Values are mean \pm s.e.m. for 5 mice/group. A significant difference between scrotal and abdominal testes (as assessed using $t$ tests) was only observed with hCG stimulation on Day 30.

\section{Discussion}

These results demonstrate that in the mouse there is a sharp increase in the steroidogenic capacity of the testes around 25 days after birth. These results correlate with the data from Jean-Faucher et al. (1978) which show that testosterone concentrations in the testis and blood show marked increases around the same time. Anakwe \& Moger (1984) have also reported that testicular androgen production in the mouse increases markedly during development although the timing of these changes was later than in the present study. The reason for this difference is not clear but may be related to the strain of mice used (Selmanoff et al., 1977; Stalvey \& Payne, 1983). The increase in testicular capacity for androgen production around 25 days may be caused by changes in Leydig cell number or Leydig cell activity. It is likely that both mechanisms are involved during development since Chase \& Payne (1983) have shown that androgen production per Leydig cell increases in the mouse between 20 and 30 days and Tapanainen et al. (1984) have reported that Leydig cell number shows a marked rise around puberty in the rat. In addition to changes in the overall capacity for steroidogenesis at puberty the types of androgens secreted showed marked changes. The increased secretion of androstanediol around 25-30 days probably reflects an increase in 
$5 \alpha$-reductase activity around puberty in the mouse as is seen in the rat and, possibly, other species (Goldman \& Klingele, 1974; Watkins et al., 1988).

The factors controlling these changes in testicular steroidogenesis during development remain uncertain. Activity of $5 \alpha$-reductase is known to be regulated by $\mathrm{LH}$ while other steroidogenic enzymes have, similarly, been shown to be affected by exogenous LH or hCG in the rat (Nayfeh et al., 1975; Murono \& Payne, 1979; O'Shaughnessy \& Payne, 1982). In the hypogonadal (hpg) mouse, which lacks circulating LH and follicle-stimulating hormone (FSH), treatment with $\mathrm{LH}$ is sufficient to stimulate testicular steroidogenesis to the level seen in normal adult animals (Scott et al., 1990). These results would suggest that LH alone is sufficient to induce changes in steroidogenesis around puberty. Circulating levels of immunoactive $\mathrm{LH}$ are reported to increase in the mouse between 20 and 30 days although this change may not be particularly marked (Selmanoff et al., 1977; Michael et al., 1980; Jean-Faucher et al., 1983). The increase in circulating FSH over this period is more dramatic (Selmanoff et al., 1977; Michael et al., 1980; Jean-Faucher et al., 1983) and it is possible, therefore, that an interaction between the two gonadotrophins contributes to changes in Leydig cell function during puberty. In the rat there is strong evidence that FSH can regulate Leydig cell function (Kerr \& Sharpe, 1985; Teerds et al., 1989), presumably through interaction with Sertoli cells, and the mouse may show a similar sensitivity to this hormone (Dalterio et al., 1986).

Results shown here indicate that at around the time of final testicular descent in the mouse (25 days) there is a marked increase in testicular steroidogenesis and that shortly after this period the steroidogenic response of the testes is sensitive to short-term exposure to abdominal temperature. This might suggest either that the change in temperature, due to testicular descent, induces an increase in testicular steroidogenesis by itself or that descent is required to maintain the high levels of steroidogenesis achieved around Days 25-30. Results from unilaterally cryptorchid animals support the second of these possibilities. At 25 days scrotal and abdominal testes both showed a high level of steroidogenesis, demonstrating that descent is not required to achieve an adult level of androgen production. The decrease in steroidogenesis by the abdominal testis at 30 days shows, however, that descent is required to maintain this high level of steroid production and that an extension of abdominal temperature for 5 days will inhibit normal Leydig cell development.

The temperature-sensitive regulatory mechanism controlling steroidogenesis in the testis is unknown. Different mechanisms may be involved in the short-term inhibition, seen in vitro at $37^{\circ} \mathrm{C}$, and the longer-term inhibition in the cryptorchid testis. After cryptorchidism it is clear that the capacity of the testis for steroidogenesis is decreased, even at lower scrotal temperatures. The effects of temperature, both in the short term and in the longer term, could be due to non-specific inhibition of cellular function. Munabi et al. (1984) have reported that activity of several steroidogenic enzymes increases as the temperature is raised from scrotal to abdominal temperature. This suggests that abdominal temperature does not affect Leydig cell function, in the short term, via direct changes in steroidogenic enzyme activity, although the cholesterol side-chain cleavage enzyme, the rate-limiting enzyme for steroidogenesis, was not examined in these studies. Further studies will be required to determine which component of Leydig cell function is affected by elevated temperature in the short term. In the longer term, inhibition of testicular descent with the consequent increase in temperature may have both direct and indirect effects on Leydig cell function. The indirect effects of cryptorchidism include changes in blood flow (Damber et al., 1978) and degeneration of the germinal epithelium, although it is less likely that these effects will be manifest within the short time that testes were retained, experimentally, within the abdomen in this study. It is more likely that the high level of steroidogenesis reached by 25 days cannot be maintained at elevated temperatures in the longer term. This may be due to longer-term direct effects of temperature on components of Leydig cell function such as the steroidogenic enzymes or adenylate cyclase. Alternatively, it is possible that elevated temperature may act on Leydig cell function via the paracrine relationship between this cell and the Sertoli cell. Stimulation of Sertoli cell activity generally has a trophic effect on Leydig cells (Tabone et al., 1984; Verhoeven \& Cailleau, 1986) 
although a Sertoli-derived inhibitory factor has also been described (Vihko \& Huhtaniemi, 1989). Sertoli cell activity is affected by both temperature changes and cryptorchidism and this may, subsequently, affect Leydig cell function in both the short and longer term.

\section{This study was supported by grants from the Wellcome Trust and the M.R.C.}

\section{References}

Anakwe, O.O. \& Moger, W.H. (1984) Ontogeny of rodent testicular androgen production in response to isoproterenol and luteinising hormone in vitro. Biol. Reprod. 30, 1142-1152.

Bedford, J.M. (1978) Anatomical evidence for the epididymis as the prime mover in the evolution of the scrotum. Am. J. Anat. 152, 483-508.

Cattanach, B.M., Iddon, C.A., Charlton, H.M., Chiappa, S.A. \& Fink, G. (1977) Gonadotrophin releasing hormone deficiency in a mutant mouse with hypogonadism. Nature, Lond. 269, 338-340.

Chase, D.J. \& Payne, A.H. (1983) Changes in Leydig cell function during sexual maturation in the mouse. Biol. Reprod. 29, 1194-1200.

Dalterio, S.L., Suter, D.E., Schwartz, N.B., Mayfield, D. \& Rettori, V.B. (1986) Differential effects of folliclestimulating and luteinising hormones on testosterone production by mouse testes. Steroid Biochem. 25, $149-156$.

Damber, J.E., Bergh, A. \& Janson, P.O. (1978) Testicular blood flow and testosterone concentrations in the spermatic venous blood in rats with experimental cryptorchidism. Acta endocr., Copenh. 88, 611-618.

Dufau, M.L., Catt, K.J. \& Tsuruhara, T. (1971) Gonadotrophin stimulation of testosterone production by the rat testis in vitro. Biochem. Biophys. Acta 252, 574-579.

Farrer, J.H., Sikka, S.C., Xie, H.W., Constantinide, D. \& Raifer, J. (1985) Impaired testosterone biosynthesis in cryptorchidism. Fert. Steril. 44, 125-132.

Goldman, A.S. \& Klingele, D.A. (1974) Developmental defects of testicular morphology and steroidogenesis in the male rat pseudohermaphrodite and response to testosterone and dihydrotestosterone. Endocrinology 94, 1-16.

Gomes, W.R., Butler, W.R. \& Johnson, A.D. (1971) Effect of elevated ambient temperature on testis and blood levels and in vitro biosynthesis of testosterone in the ram. J. Anim. Sci. 33, 804-807.

Hagenas, L. \& Ritzen, E.M. (1976) Impaired Sertoli cell function in experimental cryptorchidism in the rat. Molec. cell. Endocrinol. 4, 25-34.

Hall, P.F., Kew, D. \& Mita, M. (1985) The influence of temperature on the functions of cultured Sertoli cells. Endocrinology 116, 1926-1932.

Jean-Faucher, C., Berger, M., de Turckheim, M., Veyssiere, G. \& Jean, C. (1978) Developmental patterns of plasma and testicular testosterone in mice from birth to adulthood. Acta endocr., Copenh. 89, $780-788$.

Jean-Faucher, C., Watik, N.E., Berger, M., de Turckheim, M., Veyssiere, G. \& Jean, C. (1983) Ontogeny of the secretory pattern of LH and FSH in male mice during sexual maturation. Int. J. Androl. 6, 575-584.
Jegou, B., Peake, R.A., Irby, D.L. \& de Kretser, D.M. (1984) Effects of induction of experimental cryptorchidism and subsequent orchidopexy on testicular function in immature rats. Biol. Reprod. 30, 179-187.

Kerr, J.B. \& Sharpe, R.M. (1985) Follicle-stimulating hormone induction of Leydig cell maturation. Endocrinology 116, 2592-2604.

Kerr, J.B., Rich, K.A. \& de Kretser, D.M. (1979) Effects of experimental cryptorchidism on the ultrastructure and function of the Sertoli and peripubertal tissue of the rat testis. Biol. Reprod. 21, 823 -838.

Michael, S.D., Kaplan, S.B. \& Macmillan, B.T. (1980) Peripheral plasma concentrations of LH, FSH prolactin and $\mathrm{GH}$ from birth to puberty in male and female mice. J. Reprod. Fert. 59, 217-222.

Moore, C.R. \& Chase, H.D. (1923) Heat application and testicular degeneration. Anat. Rec. 26, 344-403.

Munabi, A.K., Cassorla, F.G. \& D'Agata, R. (1984) The effects of temperature on the activity of testicular steroidogenic enzymes. Steroids 43, 325-331.

Murono, E.P. \& Payne, A.H. (1979) Testicular maturation in the rat. In vivo effect of gonadotrophins on steroidogenic enzymes in the hypophysectomised immature rat. Biol. Reprod. 20, 91 I-917.

Nayfeh, S.N., Coffey, J.C., Hansson, V. \& French, F.S. (1975) Maturational changes in testicular steroidogenesis: hormonal regulation of $5 \alpha$-reductase. $J$. Steroid Biochem. 6, 329-335.

O'Shaughnessy, P.J. \& Payne, A.H. (1982) Differential effects of single and repeated administration of gonadotrophins on testosterone production and steroidogenic enzymes in Leydig cell populations. J. biol. Chem. 257, 1 1503-11509.

Rhynes, W.E. \& Ewing, L.L. (1973) Testicular endocrine function in Hereford bulls exposed to higher ambient temperature. Endocrinology 92, 509-515.

Scott, I.S., Charlton, H.M., Cox, B.S., Grocock, A., Sheffield, J.W. \& O'Shaughnessy, P.J. (1990) Effect of LH injections on testicular steroidogenesis, cholesterol side-chain cleavage P450 mRNA content and Leydig cell morphology in hypogonadal $(h p g)$ mice. J. Endocr. 125, 131-138.

Seethalakshmi, L. \& Steinberger, A. (1983) Effect of cryptorchidism and orchidoplexy on inhibin secretion by rat Sertoli cells. J. Androl. 4, 131-135.

Selmanoff, M.K., Goldman, B.D. \& Ginsburg, B.E. (1977) Developmental changes in serum luteinising hormone, follicle stimulating hormone and androgen levels in males of two inbred strains. Endocrinology $100,122-127$.

Sheffield, J.W. \& O'Shaughnessy, P.J. (1989) Effect of injection of gonadotrophin-releasing hormone on 
testicular steroidogenesis in the hypogonadal ( $h p g$ ) mouse. J. Reprod. Fert. 86, 609-617.

Stalvey, J.R.D. \& Payne, A.H. (1983) Luteinising hormone receptors and testosterone production in whole testes and purified Leydig cells from the mouse: Differences among inbred strains. Endocrinology 112, 1696-1701.

Tabone, E., Benahmed, M., Reventos, J. \& Saez, J.M. (1984) Interactions between immature porcine Leydig cells and Sertoli cells in vitro. An ultrastructural and biochemical study. Cell Tissue Res. 237, 357-365.

Tapanainen, J., Kuopia, T., Pelliniemi, L.J. \& Huhtaniemi, I. (1984) Rat testicular endogenous steroids and number of Leydig cells between the fetal period and sexual maturity. Biol. Reprod. 31, 1027-1035.

Teerds, K.J., Closset, J., Rommerts, F.F.G., de Rooij, D.G., Stocco, D.M., Colenbrander, B., Wensing, C.J.G. \& Hennen, G. (1989) Effects of pure FSH and LH preparations on the number and function of Leydig cells in immature hypophysectomized rats. J. Endocr. 120, 97-106.
Van Straaten, H.W.M., Ribbers-de Ridder, R. \& Wensing, C.J.G. (1978) Early deviations of testicular Leydig cells in the naturally unilateral cryptorchid pig. Biol. Reprod. 19, 171-176.

Verhoeven, G. \& Cailleau, J. (1986) Specificity and partial purification of a factor in spent medium from Sertoli cell-enriched cultures that stimulates steroidogenesis in Leydig cells. J. Steroid Biochem. 25, 393-402.

Vihko, K.K. \& Huhtaniemi, I. (1989) A rat seminiferous tubule epithelial factor that inhibits Leydig cell cAMP and testosterone production: mechanism of action, stage-specific secretion and partial characterisation. Molec. cell. Endocr. 65, 119-127.

Watkins, W.J., Goldring, C.E.P. \& Gower, D.B. (1988) Properties of 4-ene-5a-reductase and studies on its solubilization from porcine testicular microsomes. $J$. Steroid Biochem. 29, 325-331.

Wettemann, R.P. \& Desjardins, C. (1979) Testicular function in boars exposed to elevated ambient temperature. Biol. Reprod. 20, 235-241.

Received 15 June 1990 